\title{
The United States and the Arab Spring
}

\author{
Timo Kivimäki
}

Department of Political and Economic Studies, University of Helsinki, P.O. Box 54, 00014, University of Helsinki, Finland; Tel.: +358 503081270; E-Mail: timo.kivimaki@helsinki.fi

Submitted: 25 April 2013 | In revised form: 29 May 2013 | Accepted: 5 June 2013 |

Published: 3 July 2013

\begin{abstract}
This article reveals, by studying correlative relationships between US regime support and regime properties, that the US foreign policy in the Middle East has traditionally helped governments to limit the political participation of Islamists, communists, enemies of Israel and populations that could be hostile to the US oil interests. This way the US economic and strategic security interests have contributed to human insecurity in the region. With the exception of the last interest, the US has relaxed its support for repression of the abovementioned groups. This seems to be one of the international factors that made the Arab Spring possible.
\end{abstract}

Keywords: autocracy; democracy; human security; Middle East; sovereignty; United States

\section{Introduction}

Human security of individuals depends on many things, not just on political systems. Yet, restrictions to political participation, lack of openness and competitiveness of executive recruitment, and especially the lack of constraints on the chief executive's policies and actions all predict authoritarian violence, which is definitely a threat to human security. According to Rudoph Rummel, more than six times more people were killed by their governments than by all the wars combined during the 20th century [1]. In this sense, the fall of brutal autocrats during the Arab Spring constituted progress for human security.

Human security and the change of a repressive government can be brought about in many ways. In the Arab Spring ordinary people took center stage. At the same time, political discourse on the Responsibility to Protect (R2P), let alone the discourses giving legitimacy to international military interventions in the name of democracy, also highlight the role of international state actors in the promotion, and destruction of human security. Recently up to $60 \%$ of people killed in wars were killed by wars (Libya, Iraq and Afghanistan) that were justified by references to human security, democracy and human rights (calculated by the author on the basis of best estimates for 2011, the last year of the data published yet [2]). This is why it is still relevant to ask how states really influence each other and what human security implications this influence could really have. This article will focus on these questions in the context of the Arab Spring and argues that the ending of the US support of authoritarian suppression of the 
political participation of Islamists and anti-Israel movements in the Arab world could have affected the downfall of autocracy in several Arab countries. Furthermore, this article argues that greater openness provided by WikiLeaks about this change in the US policy possibly triggered this change.

\section{Earlier Studies and the Argument of This Study}

The successful toppling of autocrats in Tunisia, Egypt, Libya (and Yemen) has often been attributed to the popular motives of opposing despots. The failure to bring about development (legitimacy by means of performance) has been pointed to by several scholars [3-8]. Filipe Campante and Davin Chor and Katerina Dalacoura specify the argument by showing that grievances, especially that of unemployment, held by well-educated people foreshadow problems for autocrats $[9,10]$. According to Samuel Huntington "The higher the level of education of the unemployed, ...the more extreme the destabilizing behavior which results" [11]. In addition to unemployment, economic policies that discriminate against the well-educated middle class have been associated with the success of change in Tunisia, Egypt and Libya [12].

Nonetheless, grievances that motivate and initiate revolts can also be purely political. Abrams applied the logic of relative deprivation to political grievances by explaining the appraisals of the Middle East as a response to the increasingly violent repression of the non-violent political opposition and also to the reversal of the modest beginnings of early democratic signs [11].

Some explanations emphasize the resources and opportunities of the potential rebels. This article will focus exactly on the modalities of democratic revolt. People are able to topple autocratic regimes, only when the autocrat fails to keep his/her order intact [13] and this condition is partly dependent on whether or not the opposition has the resources, the education and the time for mounting such a challenge $[9,14]$. The availability of new communication media with Facebook, text messaging etc. have been considered to have been among the facilitators of change in the Middle East [4,14-17]. In contrast, an ideational emancipation, the ability to imagine democratic models that are not copied from American textbooks on political science, has also been seen as a necessary condition to the process of democratization [18]. Finally, a successful challenging of the rulers also required the political awakening of the young people $[15,16,18]$, and the political (rather than militant) mobilization of religious groups. The wisdom of Przeworsky [19] about the impact on perceptions of the feasibility of democratic revolution in democratizing regions was also utilized in the analyses of the opportunities available for the toppling of autocrats in the Middle East [20].

\section{External Action....and Inaction}

Opportunities for a democratic change are not always created domestically. External political influence and intervention in domestic power battles is another factor that affects the opportunities of peoples who might have other motives for toppling their respective autocratic regimes. On the one hand, much attention has recently been paid to international efforts to help the opposition topple their despots. Vali Nasr, for example, criticizes Obama's administration for rejecting the initiatives of the State Department for greater activism in support of democracy. Instead, he claims, the White House is "in a retreat" from the region [21]. At the same time these efforts at democratization often end up as imperialism that does not serve the human security in dictatorships [22]. This article will focus precisely on those inputs into those opportunities that topple autocrats that emanate from the political interventions into the domestic power struggles of democratizing states made by the big powers. Seven out of the ten most spectacular changes towards democracy that occurred after the First World War were at least partly influenced by international manipulation of the military power balance of the affected country [23]. However, in most cases the change was related to the ending of support for an autocrat by a foreign power. In Latin America, the US support of autocrats ended with the human rights campaign of President Jimmy Carter, and with the anti-drug warfare of President Ronald Reagan and what followed was a wave of democratization throughout the region. The wave of democratization in Eastern Europe, again, was made possible by the collapse of the Soviet Union and its support for the communist autocrats. The ending of the Soviet intervention for the communist autocrats in Latvia, Estonia, Lithuania, Bulgaria and Czechoslovakia resulted in the democratization of half of the ten countries that had experienced the most profound democratization after the First World War [23].

\section{Can It Be the WikiLeaks?}

The question related to foreign impacts is, whether there was a foreign power that withdrew its support from the autocrats. If such support from a power existed in the Middle East, it had to be from the US since only the American influence can have had such a decisive role in the shaping of polities in the region. A thesis that this was the case has already been presented. Ruthie Blum surprisingly accuses the US for abandoning its autocratic allies and thus making available space for anti-Israeli Islamists to take over [24]. In contrast, other scholars have been more critical of the US with its support for autocrats in the past, and more recently they have been critical of the US policy that has not supported the democratic movements sufficiently [21], and these scholars are 
now pleased to have seen the autocrats overthrown. The thesis of the Arab Spring being influenced by the refusal of the US to support its old allies was well presented by the advocacy group of the main whistleblower, WikiLeaks. This organization allegedly leaked the information about the unwillingness of the US to continue its support for President Ben Ali in Tunis:

\begin{abstract}
"The US campaign of unwavering public support for President Ali led to a widespread belief among the Tunisian people that it would be very difficult to dislodge the autocratic regime from power. This view was shattered when leaked (WikiLeaks) cables exposed the US government's private assessment: that the US would not support the regime in the event of a popular uprising. While extreme economic hardship and popular discontent with (human) rights abuses had already set the stage for an uprising, this new information played a critical role in transforming the landscape of political possibilities in Tunisia. The Tunisian people finally realized that, contrary to the US government's public relations efforts, they weren't really up against the full force of the world's superpower" $[25,26]$.
\end{abstract}

Could it be that the main international push for democratization in the Middle East came as a negative act? The negative act, or non-action in this case was the refusal of the US to continue support for Ben Ali against his democratic challengers. In Egypt the US abandoned President Hosni Mubarak, who until the turmoil had received financial support matched only by the US support for Israel. In Libya the United States participated in a military operation involving the heavy bombing of Muammar Gaddafi's troops. In contrast, during President George W. Bush's regime, the country solicited Libyan support in the war on terror, tried to persuade Gaddafi to accept intelligence sharing arrangements and hoped to add Libya to the Trans-Sahara Counter-Terrorism Partnership [27]: a venture that was undoubtedly aimed against some of the individuals in the current Libyan government. It is not within the scope of this article to prove that the US policy towards some of its Middle Eastern allies, especially in the war against terror, has dramatically changed. Instead, this is taken as a given. Such a change is considered to be a subject that this article will not analyze. In addition, no proof for the argument that the sudden inaction of the US regarding support of its autocratic allies was one of the reasons for the emergence of the opportunity for the Arab Spring will be provided either. Instead the topic that this article will focus on, is the question of whether the former US policy indeed contributed to the durability of Middle East autocracy.

Thus, the main question this article tries to answer is whether or not it is true that former US support of regimes in the Middle East supported autocrats more than it did democrats. If the answer to this controversial question is no, then it will not be possible to say that the ending of such support contributed to the toppling of autocrats. Only if the overall balance of US interference and intervention in domestic affairs of the Middle East tilts in favor of autocracy, can US inaction be said actually to have helped to oust the dictators. This is why this article focuses on the question of what the overall balance of US support to domestic forces was: Was the support of the US in general in favor of democrats or dictators?

\section{Quantitative Design}

In order to answer this challenging research question, it is necessary for the analysis to go beyond gut feelings and qualitative analysis that aim at quantitative conclusions. It is known that there are cases where the US has supported democratic regimes and there are cases where the US has supported autocrats. Of these claims there are no doubts. Nevertheless, the crucial question is which pattern is the rule and which is the exception with regard to US interaction with the countries of the Middle East. In addition to revealing incidents and support and opposition of different types of regimes, one needs to reveal how often the US influence supported autocrats, and how often it supported democrats. This can be done by correlating data on polities with data on US military support and political support for regimes. The Polity IV dataset will be used for the data on polities. This database is the most used data on polities among specialists of comparative study of democratization. The definitions and operationalizations of the variables that will be used in this article will be discussed as and when these variables are introduced. The data on US support have been derived from historical analyses that will not be discussed here. However, for the sake of transparency, the coding of Middle East countries to various contemporaneous categories of US support during the years after the Second World War are shown in Appendixes 1 and 2 of this article.

Previously, I examined the relationship between changes in polities and changes in the qualities and quantities of US support [28]. My conclusions suggested that the US has generally rewarded changes towards autocracy whereas it has punished democratization. Examination of the events reveal that this was because the processes of democratization have often been spearheaded by groups who are either against Israel, against the US economic interests (mainly oil-related), or are geopolitically problematic as Islamists or socialists [28]. However, this time I wish to establish whether US support for regimes has been important for the stability of autocrats per se (and whether the ending of such support can be a crucial reason for the Arab 
Spring). It is also important to analyze how support and autocracy correlate, i.e. what is the overall balance of US influence with regards to autocracy in the Middle East. Thus, the hypothesis of this study is that it is possible that the ending of US support for autocrats facilitated the Arab Spring because the overall influence of the US regional power previously was in support of autocracy.

The temporal focus of this examination begins from the beginning of independence of the Middle East countries and also after the US became hegemonic over the region, i.e. after the Second World War. This analysis period ends at the end of the year 2010, the last year of Polity IV at the time of writing this article. Using the year 2010 as the last year of the analysis also reveals the policy of the US before the beginning of the Arab Spring. For this reason, the decision for using the year 2010 as the last year for analyzing the research question, is academically robust.

In my quantitative analysis I will reveal two sets of results, one dataset in which Turkey is treated as a Middle East nation, and the other in which Turkey is not treated as a member of the region. Iran is another borderline state. Yet it is more often than not included in the region of the Middle East and this is why I will also consider it as a Middle Eastern power in my analysis. After all, in political terms Iran is a most central actor in Middle East politics, and its experience of US influence is crucial in the construction of the political reality of power in the Middle East region. Iran, as one of the members of the "axis of evil" and the group of "tyrannies", has been central to the US argument for the need to interfere in domestic policies in order "to rescue populations". The focus is on Muslim countries, as this is the cultural and geographic area where the Arab Spring took place. Lebanon has not been dominated by Muslim regimes even though currently Muslims constitute a majority of about $60 \%$ of the population. Lebanon is naturally included in the Muslim Middle East area due to its integral affiliation within the group of the Middle East states. Since the study leaves out the examination of Israel (since the focus in on Muslim countries), there is an inherent bias against US policies of support for democracy: Israel is a democracy (within its core territory), and the US tends to support Israeli governments.

\section{US Support for Democracy...and Autocratic Violence}

Democracy in this article can be defined as the following essential interdependent elements: openness and competitiveness in executive recruitment, and competitive and regulated political participation. Autocracy, in this article, is defined by the lack of competitiveness of political participation, the regulation of participation, the lack of openness and competitiveness of executive recruitment, and the lack of constraints on the chief executive's policies and actions. Both the Democracy and the Autocracy indicator used here are an additive 11-point scale (010). These definitions follow the operationalizations of the Polity dataset $[29,30]$. It is important to note that autocracy and democracy are not mutually exclusive: a country that allows a lot of popular participation, but rules without constraints can be relatively autocratic at the same time as being relatively democratic. The US military relationship means US military aid or concessional sales of military hardware for regimes that enable them to maintain law and order. The US general assistance to the regime means political support for the regime in the form of economic aid, diplomatic support or positive publicity for the regime. The coding of political and military support can be accessed in Appendixes 1 and 2 .

\section{US Support in the Middle East Including Turkey}

Before going into correlative analysis one should make a methodological reservation here. To assess the significance of correlations one should focus on observations that are independent of each other. However, if the country is a democracy this year it is likely to have been a democracy the year before and it is likely to be a democracy the following year. The same is true for US support. Yet, correlations are relevant regardless of the interdependence between observations of each country over time as we are interested in whether US influence is currently helping autocrats or democrats, rather than in whether there is a systematic causal relationship between autocracy and US support. Even if it can be predicted that if the US supports one autocratic regime this year, then this regime will still be autocratic and that the US will still support it the following year, support over the years for a particular autocrat does affect the US's overall balance of support between democrats and autocrats.

There is a very weak but highly significant correlation $\left(0.111^{* *}\right.$, sign. $\left.0.000, \mathrm{~N}=1054\right)$ between US general support (non-military support) for regimes and democracy. However, such a correlation is missing between democracy and US military support for regimes. However, there is a stronger and more significant correlation between US general help to a regime and the regime's authoritarian character, which is more crucial for human security $\left(0.171^{* *}\right.$, sign. $0.000, \mathrm{~N}=1054)$. Thus in general, US general support has a highly significant, albeit weak, negative correlation with overall polity quality $\left(-0.165^{* *}\right.$, sign. $0.000, N=1054$ ), which indicates that over the study period the US supported autocracies more than democracies. Furthermore, US military support and authoritarianism were highly significant, even when they were weakly correlated $(0.114 * *$, sign. $0.000, \mathrm{~N}=$ 1055). The US then, weakly supports popular participation, but it supports harsh measures taken by the 
authorities and thereby supports human insecurity more. Furthermore, it seems that US support has targeted regimes with some competitive participation, but where the security apparatus of the regimes restrict the openness of participation. Before going on to a more detailed analysis of the profiles of polities that US support for regimes favor, let us look at the archetypal regime that the US supports or opposes.

A typical US-supported country with democracy score of 1 was Tunisia before the Arab Spring, whereas a typical country opposed by the US with a democracy score 0, was the Sudan.

The first observation of these data is that the mean scores for democracy in the Middle East area are very low (clearly below the global averages) whereas the level of autocracy is high (way above global averages).

The second observation, before making the comparison between supported and opposed regimes, is that it seems that neutral countries that are neither supported nor opposed by the US, perform slightly better in terms of their development of democracy. This is clearer the closer we come to the present. Neutral regimes tend to be countries that are relatively smaller in importance for global energy production and/or are situated in less strategic locations. Competition between the global great powers has not served the human security of peoples of economically or strategically important countries very well.

The third observation that can be made about the contents of Table 1 is that the data confirm the result of the correlation analysis. The US supports both participatory and authoritarian regimes. The countries that the US opposes tend to be less authoritarian and thus the better at protecting their own people from authoritarian violence. Moreover, neutral countries score better than those countries that the US supports. Morocco (1992-1997) after its constitutional reform of 1992 and its slow democratic progress is a typical US-supported autocracy (with an autocracy score 7). Sudan at the beginning of the new millennium (2002-2004) is a typical US-opposed country, with an autocracy score of 6 . Two typical neutral countries with an autocracy score of 6 were Egypt during the last years of Anwar Sadat and Oman before the discovery of oil in the mid-1960s. These relevant periods occurred before the development of US relations and the intensification of authoritarianism with these two countries.

Table 1. Mean democracy, authoritarianism and US general support scores in the Middle East, 1946-2010.

\begin{tabular}{lcc}
\hline & $\begin{array}{c}\text { Mean level of } \\
\text { Democracy }\end{array}$ & $\begin{array}{c}\text { Mean level of } \\
\text { Autocracy }\end{array}$ \\
\hline US opposes & 0.30 & 6.41 \\
US does not support or oppose & 1.29 & 6.38 \\
US supports & 1.06 & 6.94 \\
\hline
\end{tabular}

The same pattern applies to US military support. The US tends to support more democratic but also more autocratic regimes than it opposes. The differences between militarily supported countries and those that get no military support are smaller than in the case of general support. Consequently, it seems that US military support is even less selective than US general support when one looks at the general indicatorsof democracy and authoritarianism. However, once we look at democracy and autocracy profiles we will realize that this is not the case, after all.

\section{US Support in the Middle East Not Including Turkey}

Even though US support for autocracy is more systematic that its support for democracy, the difference between the two is not great. However, if we take a narrower geographical look at the Middle East area (Table 2) and assume that the regional rationale of support for the NATO ally, Turkey, derives from European rather than Middle Eastern realities, the picture of US policies in the Middle East gets darker.

Suddenly, the difference in democratic credentials between US-supported and US-opposed regimes disappears. Moreover, a typical US-supported polity has an autocracy score of eight whereas a typical opposed or neutral country has a score of six. The picture with military support is even worse (Table 3). An average Middle East country receiving US military assistance is clearly less democratic and much more authoritarian than a country that is not involved in military cooperation with the US.

\section{The Difference between President Bush and President Obama}

After the end of the Cold War and especially after the War on Terror had begun, the discourse on humanitarian intervention gained political capital, and thus respect for national sovereignty declined. This does not, however, mean that the consistency of US support for human security is greater once there is a greater need to pursue policies that compromise state sovereignty. Furthermore, the priorities of the War on Terror also required continued support for pro-US autocracies such as Saudi Arabia. An examination of the presidency of the George W. Bush period (Table 4) reveals how counter-terrorism affected US support to the Middle East regimes. By way of contrast I will add the figures during the first two years of the presidency of Barrack Obama in parenthesis.

Clearly, the region has become less autocratic. Since the comparison here is between countries that the US supports and the ones US opposes, the general development towards democracy, especially during the past few years does not affect the conclusion about how the US supports democracy and autocracy. 
Table 2. Mean democracy, autocracy and US general support scores in the Middle East (excl. Turkey), 1946-2010.

\begin{tabular}{lcc}
\hline & Democracy & Autocracy \\
\hline US opposes & 0.30 & 6.41 \\
US does not support or oppose & 1.26 & 6.41 \\
US supports & 0.35 & 7.61 \\
\hline
\end{tabular}

Table 3. Mean democracy, autocracy and US military support scores in the Middle East (excl. Turkey), 1946-2010.

\begin{tabular}{lcc}
\hline & Democracy & Autocracy \\
\hline No military support & 0.72 & 6.63 \\
Military support & 0.31 & 7.80 \\
\hline
\end{tabular}

Table 4. Mean democracy, autocracy and US general support scores in the Middle East, for the G. W. Bush and (B. Obama) presidencies.

\begin{tabular}{lcc}
\hline & Democracy & Autocracy \\
\hline Enemies & $0.75(0.17)$ & $5.34(5.83)$ \\
Neutral & $2.67(4.00)$ & $5.00(4.00)$ \\
Allies & $1.07(1.33)$ & $6.05(5.63)$ \\
\hline
\end{tabular}

The general democratization happened before the US policy changed as, during the term of President Bush, the countries supported by the US still were clearly more autocratic than those the US treated with suspicion and hostility. The trend in US support did not change before the change over to the Obama presidency. During the Bush presidency the United States still supported regimes that governed with slightly greater democracy than it opposed. Nonetheless, the US also supported slightly more authoritarian regimes than that it opposed. The margin between the democracy scores of those supported and those opposed diminished, whereas the margin between autocracy scores of US friends and foes slightly widened during the George W. Bush presidency. US support scores for the George W. Bush era became even less supportive of citizens when measured by support for democracy and autocracy. If Turkey is excluded from the analysis, the difference between the times before and during President G. W. Bush is substantial. Then the US clearly opposes more democratic regimes than it supports (Table 5).

However, the Obama presidency is different. The preference for autocrats virtually no longer exists in the Obama presidency.

The presidency of George W. Bush was disastrous for US legitimacy as a supporter of democracy in the Middle East when US policy is interrogated from the perspective of military support (Table 6). Regardless of whether or not we count Turkey as a Middle Eastern power, the G. W. Bush era supported more regimes with a worse democracy score and a higher level of autocracy compared to regimes the US did not support. If one looks at Table 6 on the Middle East without Turkey the picture is grim.

As the figures in parentheses for the first years of President Obama show, US policy towards democracy is fluid. It seems that the autocratic bias has not changed in US military relationships (Table 6), whereas for US general support the bias towards supporting autocratic regimes has disappeared (Tables 4 and 5). The Obama administration's policy did give different signals to the Arabs who disapproved of or opposed their autocratic leaders.

\section{Profiles of Democracy and Autocracy}

If we then move from the blunt variables of democracy and autocracy scores towards variables that detail polities, we can illuminate some of the hidden interests and drivers behind US support or opposition. US supportive relationship for a Middle East regime is correlatively associated with high levels of regulation of chief executive recruitment. Furthermore, US support was not given to countries with a long history of military coups (even if the US has backed a few of them itself). Regulation of the recruitment of the chief executive of a country does not imply either democracy or authoritarianism, but stability. Hereditary succession can be as regulated as institutionalized elections. The correlation between US support and the degree of regulation of chief executive recruitment is the highest and most significant association in this study. This association is also a characteristic of the target country's polity regardless of whether we look at general support $(0.451 * *$, sign. $0.000, \mathrm{~N}=1054)$ or military cooperation $(0.386 * *$, sign. $0.000, \mathrm{~N}=1055)$. Regulation of executive recruitment was an even more vital criterion under President G. W. Bush's tenure as president. Clearly US support strives for stability rather than democracy or the well-being of citizens of the Middle East countries. This seems explicable, given the economic and strategic interests the US faces in the Middle East. This emphasis is often central to US definitions and objectives of its Middle Eastern strategy: "The United States has pursued a foreign policy that seeks stability in a region with abundant energy reserves but which has volatile interstate relationships" [31]. Furthermore, US strategic interests in an area that neighbored the Soviet Union required that a military relationship had to have some stability. US support is also very significantly correlated with the duration of regimes, which in turn, are associated with the predictability of developments and the stability of the situation. For example, the emphasis on stability in US relations with Egypt and Tunisia continued until the very end of President George W. Bush's stint as president. The assessment at the end of 2010 was that the US could no longer go against people who yearned for democracy and wanted to oust President Ben Ali. This revelation was disclosed by WikiLeaks in January 2011 and it was an indication of a priority change in US foreign policy in favor of giving at least some room for human rights and human security, even if this meant compromising the "stability-interests" of the US. 
Table 5. Mean democracy, autocracy and US general support scores in the Middle East (excl. Turkey), G.W. Bush and (B. Obama) Presidencies.

\begin{tabular}{lcc}
\hline & Democracy & Autocracy \\
\hline Enemies & $0.75(0.17)$ & $5.34(5.83)$ \\
Neutral & $2.67(4.00)$ & $5.00(4.00)$ \\
Allies & $0.54(0.80)$ & $6.43(6.00)$
\end{tabular}

Table 6. Mean democracy, autocracy and US military support scores in the Middle East (excl. Turkey), G. W. Bush and (Obama) Presidencies.

\begin{tabular}{lcc}
\hline & Democracy & Autocracy \\
\hline No military relations & $1.14(1.58)$ & $5.16(5.08)$ \\
Military relations & $0.49(0.78)$ & $6.63(6.09)$ \\
\hline
\end{tabular}

Despite the poor democracy record of the US supported regimes, the level of competitiveness in executive recruitment and the level of competitiveness in political participation in Middle East states on the one hand and US military support on the other are clearly correlated (competitiveness of executive recruitment: $0.241^{* *}$, sign. $0.000, \mathrm{~N}=1055$; competitiveness of political participation: $0.160 * *$, sign. $0.000, N=1055$ ) and with general support on the other hand (competitiveness of executive recruitment: $0.267^{* *}$, sign. $0.000, \mathrm{~N}=1054$; competitiveness of political participation: $0.128^{* *}$, sign. $0.000, \mathrm{~N}=1054$ ) are significantly, albeit very weakly, correlated. Clearly the centrality of democratic competition in the American policy can be seen.

Although competitive regimes are supported, US support is correlated with constraints on the openness of this competition. Executive recruitment and political participation might be competitive, but not all can participate in this competition. The openness of the executive recruitment concept has the strongest negative correlation with US support, both general and military (general support: $-0.336 * *$, sign. 0.000 , $\mathrm{N}=1054$; military support: $-0.254 * *$, sign. $0.000, \mathrm{~N}$ $=1055)$. An examination of the autocracies that the US has supported and opposed reveals what kind of restrictions to democratic participation the US supports. Recruitment and political participation are not open as Communists, Islamists and people who would be harmful to US political interests in terms of policy towards oil, are often excluded from the political process.

The problem of the lack of openness is also understandable from the point of view of US strategic and economic interests. Even when the US is ideologically committed to supporting competitive political systems, it cannot allow ideological expressions that harm its oil interests or strategic priorities within the Middle East. However, when emphasizing abstract strategic security interests, the
US has traditionally contributed to human insecurity inside Middle Eastern autocracies.

\section{US Support and Democracy and Human Rights: Extreme Cases}

The rationales of US support for elements of autocracy namely: the bias towards autocratic stability and the imposition of restrictions on political participation and the competition for executive positions against Islamists, Israel-haters, Communists and opponents of US oil interests, can also be examined by looking at the extreme cases of US support for autocrats and its opposition to democrats. If we list regimes that the United States has supported and put them in the order of their autocracy score from the most to the least autocratic regimes, at the top of the list we would get the extreme cases that the US should not have supported if it were interested in the promotion of human security. This is what I have done in Table 7: the cut-off point is the autocracy score 10, which is the highest level of autocracy in the Polity data. All the regimes listed below belong to that category.

I now order the data for countries the US opposed in the order of their autocracy scores, starting from the least autocratic countries, in Table 8.

Table 7. Most autocratic regimes that US has supported.

\begin{tabular}{lcc}
\hline Country & Regime years & Autocracy score \\
\hline Iran & $1953-1978$ & 10 \\
Jordan & $1974-1983$ & 10 \\
Saudi Arabia & $1946-2010$ & 10 \\
Kuwait & $1976-1989$ & 10 \\
Bahrain & $1971-1992$ & 10 \\
Qatar & $1985-2010$ & 10 \\
Oman & $1973-1990$ & 10 \\
\hline
\end{tabular}

Table 8. Least autocratic regimes that the US has opposed.

\begin{tabular}{lcc}
\hline Country & Regime years & Autocracy score \\
\hline Sudan & $1967-1968$ & 1 \\
Iran & $1997-2003$ & 1 \\
Lebanon & 2005 & 1 \\
Yemen North & $1967-1972$ & 3 \\
Yemen & 2005 & 3 \\
Sudan & $2005-2010$ & 4 \\
Iran & $1951-1952$ & 4 \\
Iraq & $1958-1967$ & 5 \\
Yemen South & 1969 & 5 \\
Sudan & $2002-2004$ & 6 \\
Iraq & $1982-1996 ; 2004-2010$ & 6
\end{tabular}


Many of the regimes (of Table 8) demonized in the Western media are nowhere near as autocratic as all of the US allies of Table 7. In fact every one of the regimes listed, including the currently much maligned Iranian and Sudanese governments, is less autocratic than the average Muslim regime that the US supports in the Middle East. Not even the two most autocratic regimes that US has opposed in the past, Saddam Hussein's Iraq or the socialist, pro-Soviet regime of Algeria of the mid-1960s ever had an autocracy score of 10 .

Each of the US-supported regimes that had an autocracy score 10 were major oil producers, and all of them have or have had a stable but ruthless political system. The US is addicted to oil, and it sells out its principles of human security to get what it needs, as any addict would.

It seems from Table 8 that the US has opposed relatively less-autocratic countries when a) their popular will went against the crucial interests of US energy policies (Iran 1951-1952 being the best example), and US global missions against communism (South Yemen 1969) or against Islamic terrorism (Iran, 1997-2008, Sudan 2002-2008), or b) when their relations with the US were severed by them having a negative stand on Israel (Sudan 1967-1968). The pursuance of such opposition has often occurred in ways that undermine the principle of human security.

If we look at the countries for which Barack Obama's regime relaxed its rule of supporting stable regimes, and allowed people to topple their leaders, we can see that these countries were not crucially important oil producers. Their respective democratic oppositions were moderately Islamist and they did oppose Israel, but the Arab Spring in these countries never threatened the US oil interests. It seems that Obama could tolerate human security progress even in countries that were likely to turn Islamist and antiIsrael. However, the US war on terror was not to be compromised, and thus popular pressures were not allowed to hamper US operations in Yemen. In addition, popular preferences were still suppressed in those US allied countries in which the promotion of such preferences could have helped the geopolitical interests of Iran (such as in Iraq and Bahrain). However, US resolve was most unyielding in the countries in which the US energy interests where threatened (Bahrain and Saudi Arabia). Whether the new energy solutions that will reduce US energy dependence on the Middle East will affect this driver for the support of stable but autocratic regimes of oil producing nations remains to be seen.

\section{Conclusions and Discussion}

Comparison of polity profiles of regimes that the United States either supports or opposes in addition to an analysis of the extreme cases of US support and opposition seem to produce the same conclusions. The main conclusions of this study support the view which can be summarized as follows:

1. In general, the United States has supported more autocratic regimes than it has opposed. In this sense US support of regimes seems to have contributed to human insecurity.

2. In general the US military relationship facilitated autocratic governments, i.e. governments whose polity allows for a more brutal oppression of their people than those regimes for which the US eschews such a military relationship.

3. The US supports seven regimes with the highest autocracy score of 10: i.e. regimes that are more autocratic than the most autocratic regimes that the US has opposed.

4. Many of the countries that the US has been most passionate in opposing, i.e. those countries that the US policy most frequently denies the normal diplomatic rights to which all sovereign nations are due, are relatively democratic and much less autocratic than the countries the US supports in general.

The polity profiles of the regimes that the US either supports or opposes in the Middle East provide important explanations as to why the balance of US influence in domestic policies in the Middle East countries favors autocratic governments. The analysis above corroborates the findings based on the observation of polity changes and the qualitative analysis published by Marwan Bishara and myself $[28,32]$. According to Bishara, support for autocrats is because the US sees the Middle East through the prism of oil, Israel, and terrorism, and that all of these viewpoints are impediments to the US commitment to pursuing democracy, human rights and freedom [32]. The US preferred the controlled chief executive recruitment in Middle East countries, especially in those countries where there was a risk of communists (during the cold war), Islamists (during the War on Terror), or haters of Israel taking over. The US also supported the durability of these polities, especially in oil producing countries. Clearly, all of these factors are decisive in what lies behind the traditional US support for autocrats in the Middle East.

The oil and gas-related interests for supporting autocrats can be understood easily by integrating this observation with the literature of political economy. Oil is important to the US strategically, whereas oil interests also affect the behavior of the US towards Middle East states due to the influence wielded by the oil companies.

Oil is a strategic commodity and a necessity of modern industry, thus access to oil-based energy has long been crucial for the strategic and economic interests of the United States. In addition to it being a necessity for American prosperity, it has been 
instrumental in the setting of strategic goals, including the ability of the US to promote democracy in the world. This paradox between US economic interests with regards to oil and the wider espoused US global strategic goal of democracy was made very explicit in the previous US president's (George W. Bush) analysis of US policies on the Middle East [31]. This dichotomous linkage between strategy and support for oil autocrats explains the approach of the US in limiting popular expression in favor of Islamism (or Iran), and communism.

In addition to global interests, energy influences US policies about protecting the investments of American oil companies in Middle Eastern oil. Oil exploration requires a huge investment before it starts producing any profits and after this initial investment the assets of the investors are fixed and immobile and therefore at the mercy of any change in policy. Consequently, it is clear that the investor is keen on rules that enable the continuation of the business. According to Hirschman [33], this creates a situation where the investor is left with the strategy of trying to influence the host country: leaving the country is not an option. When the investment is crucial to national interest, it is likely that the logic of power forces the country of the investor to pursue strategies that aim at controlling the polity of the host country. It does so to ameliorate the vulnerability of strategically important investments. The strong support given by the United States to friendly dictators (regimes listed in Table 7), the American preference for controlled chief executive recruitment in host countries, the support for the continuity of favorable polities in oil countries testify to this logic of immobile, fixed assets that explain the interventions of US interests in securing access to oil in the Middle East.

In addition to vital pressing economic motives, US policy has to adjust regional approaches to global priorities and this necessarily implies compromises to optimal regional strategies. Amaney A. Jamal has claimed in his book entitled: Of Empires and Citizens that "democracy may not suit the strategic interests of the United States" in the Arab world [34]. The global conflicts against global communist dictators and terrorism have sometimes meant that a Middle East government's softness on communism or on terror had to be punished or prevented or nullified by subversive means, even when governments were relatively democratic. Furthermore, as seen in Table 8, some of the pro-Soviet regimes (South Yemen and Sudan at the end of the 1960s, Iran 1951-1952) and even more often some of the religiously oriented governments that have had a sympathetic attitude towards some of the organizations that the US categorizes as terrorist (Lebanon 1985, Iran in the 2000s, and Sudan today) are somewhat less autocratic in general than other regimes in the Middle East. These regimes cannot win US support, as this support, even if positive for human security in the
Middle East, could hamper the American global fight against the forces of autocracy. Meanwhile, governments with few democratic credentials can get a favorable reception from the United States if they have a favorable attitude towards the US and its global allies.

A lesser, but still important intervening interest that explains America's occasional support for repression, is the US's support for the power, security and welfare of Israel. Whether this support is due to the Second World War's great narrative, which partly legitimizes US leadership in the world, or to the extensive domestic power of the American Jewish community [35], or to something else cannot be concluded on the basis of this study. However, what can be said on the basis of the analysis above is that the US has had to help autocrats stay in power to support the strategic goal of helping Israel. The case of marginalizing the democratically elected Hamas in Palestine, instead of trying to isolate it from the radicals involved in civilian targeting, is a good example of this. The subversive punishment of the Sudan in the mid-1960s and the refusal to endorse Iran's democratic development in the 1980 s and in the 1990s were partly related to the upholding of this partisan support. Iran, obviously, did not become a perfect democracy after its theocratic revolution while the human security situation in the country has deteriorated during the recent years. Yet, according to Polity data, the country became one of the most democratic and least autocratic countries in the Middle East, and held that position even during President Bush's campaign against tyrants (Iranian leaders included).

Although claims that US democracy support is corrupted by oil interests, strategic interests of resisting Islamism (and Iran), the will of the US to defend Israel are not new; these strategic interests, as causal factors, had not been tested systematically before this study. This is why there still are analyses that assume, as a given, that the US influence overall is in favor of democracy against totalitarian autocrats, and that the question is just whether the US is doing enough to support democracy $[21,36]$. This study together with my study of US reactions to changes of polities [28] clearly show that the inaction of the US in the Muslim Middle East during the Arab Spring would be more beneficial for human security than any traditional US action. Thus we should not take it for granted that the democratic superpower necessarily has a positive effect on democracy in the Middle East. The opposite is established here. The analysis above suggests that the US has already done too much and that it is a blessing for the human security and democracy of the region that Barack Obama's US administration is currently in retreat or less resolute in supporting its autocratic Middle Eastern allies. Thus, the most likely conclusion is that it has been US inaction rather than US action that contributed to Arab Spring. 
What has been shown above is not proof that it was the US inaction that triggered the Arab Spring. It is obvious that other factors were crucial. However, without the traditional weight of US influence in favor of autocracy, the claim of US inaction giving rise to the opportunities in the Arab world for people to oust their autocrats would have been impossible to make. The fact that there seems to be an overall balance of US influence in favor of autocrats and that WikiLeaks revealed the evaporation of US support for Ben Ali makes it plausible that the US was, after all, somehow behind the collapse of brutal autocrats in the Middle East. Whether this was actually the case should be further studied by tracing the motivations of the democratic Arab rebels, their knowledge of and trust in WikiLeaks, whether their facebook, and text messages referred to the new opportunities offered by the US inaction, and whether they talked about the WikiLeaks revelations. Yet, such research would be useless before it can be shown that the US had indeed supported autocracy and that this policy had changed with Obama. This was proven in this study (not that the US was necessarily an influence or that WikiLeaks was the trigger).

The crucial oil states have not lost the support of the US, and thus they have not managed to get rid of their autocratic obstacles to human security. Instead

\section{References and Notes}

1. Rummel RJ. Death by Government. New Bruswick, NJ, USA: Transaction Publishers; 1994.

2. UCDP. Battle-Related Deaths Dataset v.5-2012, Uppsala Conflict Data Program, Uppsala University. 2012. Available from: www.ucdp.uu.se (accessed on 1 July 2013).

3. Abrams E. Dictators Go, Monarchs Stay American Policy Before and After the Arab Spring. Commentary. 2012;134(3):26-31.

4. Lynch M. The Arab Uprising: The Unfinished Revolutions of The New Middle East. New York, NY, USA: Public Affairs; 2012.

5. Bradley JR. After the Arab Spring: How the Islamists Hijacked the Middle East Revolts. Houdmills. UK: Palgrave Macmillan; 2012.

6. Menaldo V. The Middle East and North Africa's Resilient Monarchs. Journal of Politics. 2012;74(3): 707-722.

7. Nega B, Schneider G. Things Fall Apart: Dictatorships, Development, and Democracy in Africa. Journal of Economic Issues. 2012;46(2):371-382.

8. Tobin S. Jordan's Arab Spring: The Middle Class and Anti-Revolution. Middle East Policy. 2012;19(1): 96-109.

9. Campante FR, Chor D. Why was the Arab World Poised for Revolution? Schooling, Economic Opportunities, and the Arab Spring? Journal of Economic Perspectives. 2012;26(2):167-188. the US tried to prevent them from moving against autocracy both in Saudi Arabia and in Bahrain. Thus the change in the US attitude towards Islamist and anti-Israel popular movements could be among the explanations of the Arab Spring. Also, this should be further studied by focusing on the differences in the US policies towards oil states and non-oil states. If there were a clear difference between how the US policy developed towards the two categories of states, this could further consolidate the hypothesis that the change in the US attitude towards potentially Islamist non-oil states could have been one of the external conditions of the Arab Spring. In any case, the fact that the US used to support autocrats, and that it stopped this support for autocrats of non-oil states just before the Arab Spring suggests that it is already quite plausible that the US change was one of the causes of the Arab Spring, and that the revelation of this change by WikiLeaks was a trigger for considerable human security upgrade in the region. In any case, greater transparency early on about the US support of autocracy, despite the country's prodemocracy rhetoric, could have increased the political costs involved in this double standard decades ago. This could have generated the international conditions conducive for the Arab Spring even sooner.

10. Dalacoura K. The 2011 uprisings in the Arab Middle East: political change and geopolitical implications. International Affairs. 2012;88(1):63-79.

11. Huntington SP. Political Order in Changing Societies. New Haven, CT, USA: Yale University Press; 1968.

12. Kandil H. Why did the Egyptian Middle Class March to Tahrir Square? Mediterranean Politics. 2012;17(2):197-215.

13. Leenders R, Heidemann S. Popular Mobilization in Syria: Opportunity and Threat, and the Social Networks of the Early Risers. Mediterranean Politics. 2012;17(2):139-159.

14. Worrall J. Oman: The "Forgotten" Corner of the Arab Spring. Middle East Policy. 2012;19(3):98115.

15. Murphy E. Problematizing Arab Youth: Generational Narratives of Systemic Failure. Mediterranian Politics. 2012;17(1):5-22.

16. Desrues T. Moroccan Youth and the Forming of a New Generation: Social Change, Collective Action and Political Activism. Mediterranean Politics. 2012;17(1):23-40.

17. Saleh N. Egypt's digital activism and the Dictator's Dilemma: An evaluation. Telecommunications Policy. 2012;36(6):476-483.

18. Dabashi H. The Arab Spring: The End Of Postcolonialism. London, UK: Zed Books; 2012.

19. Przeworski A. Democracy and the Market: Political and Economic Reforms in Eastern Europe and 
Latin America. Cambridge, UK: Cambridge University Press; 2012.

20. Hinnebusch R. Syria: From "authoritarian upgrading" to revolution? International Affairs. 2012;88(1):95-113.

21. Nasr V. The Dispensable Nation. American Foreign Policy in Retreat. Garden City, NY, USA: Doubleday; 2013.

22. Çubukçu A. The Responsibility to Protect: Libya and the Problem of Transnational Solidarity. Journal of Human Rights. 2013;12(1):40-58.

23. Kivimäki T. Can the international community help prevent conflict in Burma/Myanmar? In: Lagerkvist J, editor. Between Isolation and Internationalization: The State of Burma. Stockholm, Sweden: Swedish Institute of International Affairs; 2008.

24. Blum R. To Hell in a Handbasket: Carter, Obama, and the "Arab Spring". New York, NY, USA: RVP Publishers; 2012.

25. Bradley Manning Support Group. 2012. Available from: http://www.bradleymanning.org/wpcontent/uploads/2011/08/WikiLeaks2.pdf (accessed on 1 July 20013).

26. White G. This is the WikiLeak That Sparked The Tunisian Crisis. Business Insider. 2011. Available from: http://www.businessinsider.com/tunisia-wikileaks2011-1 (accessed on 1 July 2013).

27. St John RB. Libya and the United States: A Faustian Pact? Middle East Policy. 2008;XV(1):133148.

28. Kivimäki T. Democracy, Autocrats and U.S.
Polices. Middle East Policy. 2012;XIX(1):64-71.

29. Marshall MG, Jaggers K. Polity IV Project. Political Regime Characteristics and Transitions, 18001999, Dataset User Manual. 2000. Available from: www.bsos.umd.edu/cidcm/inscr/polity (accessed on 1 July 20013).

30. Eckstein H. Patterns of Authority: A Structural Basis for Political Inquiry. New York, NY, USA: John Wiley \& Sons; 1975. Available from: http://www. systemicpeace.org/polity/polity4.htm (accessed on 1 July 2013).

31. Bush GW. President Bush Discusses Freedom in Iraq and Middle East. Office of the White House Press Secretary, remarks by the President at the 20th Anniversary of the National Endowment for Democracy. 2003 Nov 6. Available from: http://georgewbushwhitehouse.archives.gov/news/releases/2003/11/200 31106-2.html (accessed on 1 July 2013).

32. Bishara M. The Invisible Arab: The Promise and Peril of the Arab Revolution. New York. NY, USA: Nation Books; 2012.

33. Hirschmann AO. Exit, Voice, and Loyalty. Cambridge, UK: Cambridge University Press; 1970.

34. Jamal A. Of Empires and Citizens: ProAmerican Democracy or No Democracy at All? Princeton, NJ, USA: Princeton University Press; 2012.

35. Mearsheimer JJ, Walt SM. The Israel Lobby And U.S. Foreign Policy. Middle East Policy. 2006;XIII(3):29-87.

36. Patterson E. Obama and Sustainable Democracy Promotion. International Studies Perspective. 2012;13(1):26-42. 
Appendix 1. US general support for the Middle East regimes.

\begin{tabular}{|c|c|c|c|}
\hline Country & US Support & Neutrality & US Opposition \\
\hline Algeria & 1979-2010 & & \\
\hline Bahrain & 1971-2010 & & \\
\hline Egypt & $1946-1952 ; 1979-2010$ & & \\
\hline Iran & $1953-1978$ & & \\
\hline Iraq & $1980-1988 ; 2003-2010$ & 1946-1957; 1989 & 1958-1979; 1990-2002 \\
\hline Jordan & 1957-1990; 1992-2010 & 1946-1956; 1991 & \\
\hline Kuwait & $1963-2010$ & & \\
\hline Lebanon & 1946-1958; 1983 & $\begin{array}{l}\text { 1959-1982; 1984-2000; } \\
2005-2010\end{array}$ & 2001-2005 \\
\hline Libya & & $1952-1968 ; 2003-2010$ & 1969-2002 \\
\hline Morocco & $1956-2010$ & & \\
\hline Oman & 1973-2010 & 1946-1972 & \\
\hline Qatar & 1985-2010 & 1971-1984 & \\
\hline Saudi Arabia & $1946-2010$ & & \\
\hline Sudan & 1972-1973; 1977-1985 & 1956-1966; 1986-1988 & $\begin{array}{l}\text { 1967-1971; 1974-1976; } \\
1989-2010\end{array}$ \\
\hline Syria & 1949 & $\begin{array}{l}\text { 1946-1948; } 1950-1962 ; \\
1970-1999\end{array}$ & 1963-1969; 2000-2010 \\
\hline Tunisia & $\begin{array}{l}\text { 1959-1984; 1986-1987; } \\
1992-2010\end{array}$ & 1985; 1988; 1990-1991 & \\
\hline Turkey & $1947-2010$ & 1946 & \\
\hline UAE & $1971-2010$ & & \\
\hline Yemen & $1990-2004 ; 2006-2010$ & & 2005 \\
\hline Yemen, North & 1962-1966; 1979-1990 & $1946-1961 ; 1973-1978$ & 1967-1972 \\
\hline Yemen, South & & $1967-1968$ & 1969-1990 \\
\hline
\end{tabular}

Appendix 2. US military support for the Middle East regimes.

\begin{tabular}{lll}
\hline Country & Military Cooperation & No Military Cooperation \\
\hline Algeria & $1992-2010$ & $1946-1991$ \\
Bahrain & $1971-2010$ & \\
Egypt & $1979-2010$ & $1946-1978$ \\
Iran & $1953-1978$ & $1946-1952 ; 1979-2010$ \\
Iraq & $1980-1988 ; 2003-20101953-1978$ \\
Jordan & $1957-2010$ & $1946-1956$ \\
Kuwait & $1991-2010$ & $1973-1990$ \\
Lebanon & $1950-1958 ; 1983$ & $1946-1949 ; 1959-1982 ; 1984-2010$ \\
Libya & & $1951-2010$ \\
Morocco & $1963-2010$ & $1956-1962$ \\
Oman & $1980-2010$ & $1946-2007$ \\
Qatar & $1992-2010$ & $1971-1991$ \\
Saudi Arabia & $1951-2010$ & $1946-1950$ \\
Sudan & $1972-1973$ & $1956-1971 ; 1974-2010$ \\
Syria & $1949 ; 1991$ & $1946-1948 ; 1950-1990 ; 1992-2010$ \\
Tunisia & & $1959-2010$ \\
Turkey & $1947-2010$ & 1946 \\
UAE & $2001-2010$ & $1971-2000$ \\
Yemen & $2006-2010$ & $1990-2005$ \\
Yemen, North & $1979-1990$ & $1946-1978$ \\
Yemen, South & & $1967-1990$ \\
\hline
\end{tabular}

